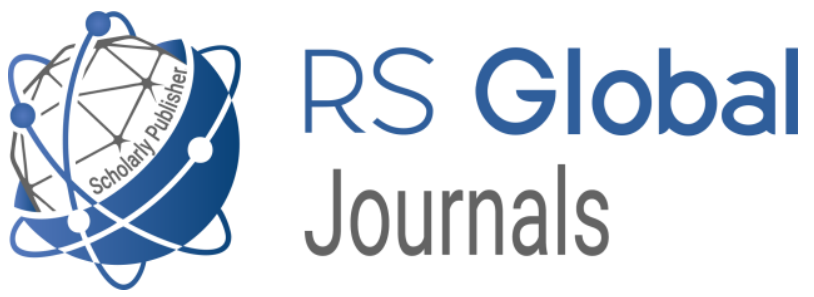

Scholarly Publisher RS Global Sp. z O.O. ISNI: 0000000484952390

Dolna 17, Warsaw, Poland 00-773

Tel: +48226022703

Email: editorial_office@rsglobal.pl

\begin{tabular}{ll} 
JOURNAL & Science Review \\
\hline p-ISSN & $2544-9346$ \\
\hline e-ISSN & $2544-9443$ \\
\hline PUBLISHER & RS Global Sp. z O.O., Poland
\end{tabular}

$\begin{array}{ll}\text { ARTICLE TITLE } & \text { REPRODUCTIVE AGE WHO PARTICIPATED IN } \\ \text { HOSTILITIES AND SUFFERED CONTUSIONS }\end{array}$

Kaminskiy Viacheslav Volodymyrovych,

$\operatorname{AUTHOR}(\mathbf{S})$

Suslikova Lidiya Viktorivna,

Serbeniuk Anastasia Valeriivna,

Dercach Andriy Dmytrovych

Kaminskiy V. V., Suslikova L. V., Serbeniuk A. V., Dercach A. D. (2020) Thyroid Dysfunction in Women of Reproductive Age

ARTICLE INFO Who Participated in Hostilities and Suffered Contusions.

Science Review. 8(35).

doi: 10.31435/rsglobal_sr/30122020/7318

DOI

https://doi.org/10.31435/rsglobal_sr/30122020/7318

RECEIVED

18 October 2020

ACCEPTED

30 November 2020

PUBLISHED

06 December 2020

LICENSE

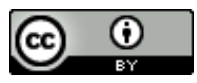

This work is licensed under a Creative Commons Attribution

4.0 International License.

(C) The author(s) 2020. This publication is an open access article. 


\title{
THYROID DYSFUNCTION IN WOMEN OF REPRODUCTIVE AGE WHO PARTICIPATED IN HOSTILITIES AND SUFFERED CONTUSIONS
}

\author{
Kaminskiy Viacheslav Volodymyrovych, doctor of Medicine, Professor, Head of department, \\ Department of Obstetrics, Gynecology and Reproductology, Shupik National Medical Academy of \\ Postgraduate Education, Kyiv, Ukraine, \\ ORCID ID: https://orcid.org/0000-0002-5369-5817 \\ Suslikova Lidiya Viktorivna, doctor of Medicine, Professor, Director, Ukrainian State Institute of \\ Reproductology, Shupik National Medical Academy of Postgraduate Education, Kyiv, Ukraine, \\ ORCID ID: https://orcid.org/0000-0002-3039-6494 \\ Serbeniuk Anastasia Valeriivna, doctor of Philosophy, Department of Obstetrics, Gynecology and \\ Reproductology, Shupik National Medical Academy of Postgraduate Education, Clinic of \\ reproductive technologies, Kyiv, Ukraine, \\ ORCID ID: https://orcid.org/0000-0002-7212-2678 \\ Dercach Andriy Dmytrovych, Department of Obstetrics, Gynecology and Reproductology, Shupik \\ National Medical Academy of Postgraduate Education, Kyiv, Ukraine, \\ ORCID ID: https://orcid.org/0000-0002-8245-051X
}

DOI: https://doi.org/10.31435/rsglobal_sr/30122020/7318

\section{ARTICLE INFO}

Received 18 October 2020 Accepted 30 November 2020

Published 06 December 2020

\section{KEYWORDS}

reproductive health, women veterans, hormonal homeostasis, autonomic dysfunction, post-concussion syndrome.

\begin{abstract}
The article presents data on the prevalence of thyroid hormonal disorders and the establishment of their relationship between the state of mental health and the functional state of body systems in women who participated in hostilities who suffered contusions. We aimed to assessing the prevalence and effectiveness of the diagnosis of thyroid dysfunction in women of childbearing age with impaired reproductive health who participated in hostilities and suffered contusions, to improve treatment and rehabilitation measures and quality of life of these women.
\end{abstract}

Citation: Kaminskiy V. V., Suslikova L. V., Serbeniuk A. V., Dercach A. D. (2020) Thyroid Dysfunction in Women of Reproductive Age Who Participated in Hostilities and Suffered Contusions. Science Review. 8(35). doi: 10.31435/rsglobal_sr/30122020/7318

Copyright: (C) 2020 Kaminskiy V. V., Suslikova L. V., Serbeniuk A. V., Dercach A. D. This is an openaccess article distributed under the terms of the Creative Commons Attribution License (CC BY). The use, distribution or reproduction in other forums is permitted, provided the original author(s) or licensor are credited and that the original publication in this journal is cited, in accordance with accepted academic practice. No use, distribution or reproduction is permitted which does not comply with these terms.

Throughout human life, the normal state of the thyroid gland is a necessary condition for the harmonious functioning of the body. The thyroid gland is one of the most important parts of the neuroendocrine system. The main function of the thyroid gland is to maintain normal cellular metabolism by providing the body with thyroid hormones - thyroxine (T4) and triiodothyronine (T3), an integral structural component of which is iodine $[2,10]$. The thyroid gland produces about $100 \mathrm{mcg}$ of T4 per day and a small amount of T3, which is preferably formed extrathyroidally from T4 under the action of type 15 '-deiodinase. Thyroid hormones are necessary for the normal functioning and development of almost all organs and functional systems of the body, and the level of their production is determined by physiological needs and regulated by thyroid-stimulating hormone (TSH) of the pituitary gland. Thyroid hormones regulate the processes of development, maturation, specialization and functioning of almost all body tissues and are of exceptional importance for the establishment and 
development of the fetal brain, the formation of the child's intelligence, growth and maturation of the bone skeleton, reproductive system; affect sexual development, menstrual function and fertility, breast development $[1,2,10,11,19]$.

A woman's reproductive system is a finely organized system of closely interconnected structural and functional elements. The whole cascade of processes required for follicle maturation, ovulation, fertilization, corpus luteum function, preparation of the endometrium for implantation, and successful continuation of pregnancy depends on the preservation of neuroendocrine regulatory pathways, the slightest disruption of which leads to dysfunction $[14,15]$.

Nowadays, the factors that determine the relationship between the reproductive and thyroid systems are well known. The function of the reproductive organs and the thyroid gland is regulated by tropical hormones of the pituitary gland, the secretion of which is under the influence of the hypothalamus and partly of the cerebral cortex. TSH is a glycoprotein hormone produced by basophilic cells of the adenohypophysis, regulated by hypothalamic thyrotropin-releasing hormone, on the one hand, and the level of free thyroid hormones, on the other. Thyroid hormones on the principle of negative feedback suppress the production of TSH, maintaining a dynamic balance in the pituitarythyroid system. Most of T4 is in the serum in a form associated with transport proteins, and only $0.03 \%$ circulates in free form. Only free T4 (FT4) is available for transcapillary transport and entry into cell. Thyroid hormones stimulate the synthesis of sex hormone-binding globulin (SHBH) in the liver. Changes in the level of SHBH (decrease in hypothyroidism and increase in thyrotoxicosis) may have some significance in the genesis of menstrual and reproductive disorders [2, 5]. Tyroliberin stimulates the secretion by the pituitary gland not only TSH but also prolactin, so hypothyroidism increases not only the level of TSH but also prolactin. Another factor is the structural similarity of luteinizing, follicle-stimulating hormones, prolactin, human chorionic gonadotropin and thyroidstimulating hormone $[1,2,7,9,14]$.

Autoimmune thyroiditis (AIT) (Hashimoto's thyroiditis, lymphocytic thyroiditis), which affects $3-4 \%$ of the world's population) is an organ-specific autoimmune disease of the thyroid gland, in which due to chronic progressive lymphoid infiltration in women there is a gradual destructive disease of thyroid gland that is the main cause of hypothyroidism in women of reproductive age [8]. The prevalence of AIT is difficult to assess, because in the euthyroid phase it has almost no accurate diagnostic criteria. The prevalence of both TPO Antibodies carriers and hypothyroidism as a result of AIT is about 10 times higher in women than in men. Antithyroid autoantibodies as one of the signs of the disease are found in 5-26\% of women of reproductive age and 13-20\% of pregnant women $[2,8,9,12]$.

In the euthyroid phase and the phase of subclinical hypothyroidism there are no symptoms. The criteria, the combination of which allows to diagnose AIT, include $[3,6,9,10]$ :

- increase in levels of circulating antibodies to the thyroid gland (more informative is the determination of TPO Antibodies);

- detection of typical ultrasound signs of AIT (hypoechoic thyroid);

- primary hypothyroidism - subclinical or manifest (according to the level of TSH in the serum).

In the absence of at least one of these criteria, the diagnosis of AIT should be considered probable, because in itself an increase in the level of TPO Antibodies or hypoechogenic thyroid according to ultrasound does not indicate the presence of AIT. Carrier means the detection of antibodies to the thyroid gland on the background of its normal structure and function. The pathological significance of this phenomenon remains ambiguous and reaches 10-20\% in different age groups, with antibodies 5-10 times more often found in women. Determination of TPO antibodies to thyrocyte peroxidase (TPO Antibodies) is used to diagnose AIT, isolated carrier of AT-TG is rarely diagnosed. At the same time, most researchers consider it meaningless to study the level of blood pressure to assess the dynamics of treatment and prediction of AIT, as well as treatment only in the presence of antobodies to the thyroid gland $[2,4,9,13]$.

Normal development of the reproductive system occurs under the influence of gonadotropic hormones of the pituitary gland and the normal functioning of the thyroid gland. In turn, the state of the reproductive system has a pronounced effect on thyroid function, as evidenced by changes in its function during pregnancy and lactation, in patients with abnormal uterine bleeding, in girls during puberty and women during the menstrual cycle.

Hypothyroidism is a clinical syndrome caused by a persistent deficiency of thyroid hormones in the body. There are primary, secondary, tertiary and peripheral hypothyroidism. In the case of the 
primary form, which accounts for the majority of cases of this syndrome (95\%), the process that leads to the development of hypothyroidism is localized directly in the thyroid gland. If the decrease in function is due to lack or absence of stimulating effect of thyroid-stimulating hormone, it is a secondary and tertiary hypothyroidism of pituitary or hypothalamic origin, respectively (central hypothyroidism). Peripheral or tissue hypothyroidism is much less often diagnosed [2, 8]. The prevalence of hypothyroidism in the population, according to various researchers, is from 5 to $10 \%$, more often in women and with increasing prevalence with aging $[1,4,5,13,16]$.

Researchers and clinicians pay special attention to the problem called "extrathyroid pathology", which is caused by a lack of thyroid hormones. The clinic of primary hypothyroidism is often dominated by manifestations of damage to various organs and systems, including cardiovascular, urinary, hematopoietic systems, digestive tract, skin diseases, mental disorders, immune disorders. At the same time, some symptoms are mistakenly defined as an independent disease that masks the presence of hypothyroidism for a long time and leads to its delayed diagnosis. Cardiovascular manifestations - hypertension, arrhythmias (sinus bradycardia), coronary heart disease, dyslipidemia occupy the first place in the clinical manifestation of non-thyroid manifestations of hypothyroidism. From the digestive organs, there may be constipation, diarrhea, dysbiosis, gastritis, pancreatitis, dyskinesia of the biliary tract. On the part of the nervous system, hypothyroidism is manifested by headache, drowsiness, depression, inability to concentrate, memory impairment $[1,12,17,18]$.

Reducing the supply of tissues with thyroid hormones reduces resistance to infections, which is realized by chronic inflammatory processes of the upper respiratory tract, chronic tonsillitis, inflammation of the genitourinary system $[1,5,8,13]$. A number of studies in recent years have shown that structural and functional disorders of the thyroid gland can initiate imbalance of the hypothalamic-pituitary-ovarian system [3, 10, 14]. Dysfunction of one or another part of the endocrine system is determined not only by hyper- or hypoproduction of hormones, but also by changes in biological activity against the background of their normal content in the serum $[1,12,17]$.

Insufficiency or excessive levels of thyroid hormones affect almost all vital processes, as their impact is realized at the cellular and even molecular levels of all organs and systems of the body [9, 19]. In the case of a decrease in thyroxine levels (T3) and triiodothyronine (T4) by the feedback mechanism significantly increases the production of thyrotropin-releasing hormone and, accordingly, thyroid-stimulating hormone, which, in turn, stimulates the production of prolactin, initiates the secretion of inhibin B in the ovaries, inhibits the production of somatotropic hormone, causes the formation of relative hyperestrogen ovarian aromatase, decreased production of sex-binding steroid globulin, luteal phase deficiency of the menstrual cycle, ovulation and fertility disorders. Disorders of peripheral estrogen metabolism and hypoprogesteronemia in hypothyroidism are now considered as one of the mechanisms to increase the frequency of proliferative processes in target organs $[4-7,14]$.

Primary hypothyroidism is accompanied by menstrual cycle (MC) disorders. The most pronounced form of MC disorders in hypothyroidism is amenorrhea, the frequency of which in this type of thyroid pathology ranges from 1.5 to $6 \%$. MC disorders in hypothyroidism are diagnosed 3 times more often than in the general population, and some reports indicate that $\mathrm{MC}$ disorders were noted in $68 \%$ of women with hypothyroidism in $12 \%$ of cases in the control group [3,10]. It should be noted that in patients with hypothyroidism, reproductive dysfunction is detected in regulatory $\mathrm{MC}$, with 10 to $25 \%$ of women complaining of infertility, which is associated with a defective luteal phase or anovulation [11, 14]. With long-term hypothyroidism, the development of secondary hyperprolactinemia, galactorrhea and MC disorders is possible, which is due to hyperproduction of the hypothalamus TSH-RH and its stimulating effect on the production of TSH and PRL [2, 5].

Data from a 20-year follow-up study in the Wickham research showed that a positive reaction to TPO antibodies is an early predictor of hypothyroidism in cases where TSH levels are above $2.0 \mathrm{mIU} / 1[13,16]$.

According to the recommendations of the American Thyroid Association (ATA, 2017) [6], all patients who are preparing for pregnancy or become pregnant again should undergo a clinical examination. It is recommended to study the content of TSH for the following risk factors:

1. Presence of a history of hypothyroidism / hyperthyroidism or current symptoms / signs of thyroid dysfunction.

2. Positive antibodies to the thyroid gland or goiter are detected.

3. Presence of a history of previous thyroid surgery. 
4. Age over 30 years.

5. Type 1 diabetes or other autoimmune diseases.

6. History of miscarriage, premature birth, infertility, more than two pregnancies.

7. Presence in the family history of thyroid disease.

8. Pathological obesity (BMI $\geq 40 \mathrm{~kg} / \mathrm{m} 2$ ).

9. Recent introduction of iodine-containing X-ray contrasts.

10. Living in areas with iodine deficiency (from moderate to severe).

According to the latest recommendations, subclinical hypothyroidism in women planning a pregnancy should be treated with levothyroxine, and the goal of treatment is to achieve a TSH concentration $<2.5 \mathrm{IU} / 1[6,8,9]$.

With age, the overall risk of hypothyroidism increases. Often the symptoms are ignored or incorrectly attributed to other causes, which complicates the diagnosis. Accordingly, ACOG recommends determining TSH levels even in asymptomatic women starting at age 50 and every 5 years thereafter [7]. The American College of Physicians (ACP) also recommends starting periodic screening at age 50, while the ATA recommends starting screening at age 35 [10,17]. According to recent recommendations of thyrological associations it is worth considering L-thyroxine replacement therapy in younger patients $(<65$ years and TSH level $10 \mathrm{IU} / 1$ ) with symptoms suggestive of hypothyroidism [6, 8, 11].

Although there is insufficient evidence to date that levothyroxine therapy improves fertility in euthyroid TPO Antibodies-positive women, it is possible to use L-thyroxine for euthyroid TPO antibodies positive women with a history of fetal loss starting at a dose of $25-50 \mu \mathrm{g} /$ day. In other cases, there is insufficient evidence for its use in euthyroid women. With TSH> $4.2 \mathrm{IU} / 1$ in the absence of symptoms of hypothyroidism and unrealized reproductive plans for women of reproductive age, levothyroxine therapy is applicable, as the optimal level of TSH for pregnancy planning in women with subclinical and overt hypothyroidism is $0.4-2.0 \mathrm{MO} / 1[2,4,11,13]$.

Today, about 30,000 women serve in the Armed Forces of Ukraine, 17,000 women took part in the war in eastern Ukraine [1].

On October 27, 2018, the Law "On Amendments to Certain Laws of Ukraine on Ensuring Equal Rights and Opportunities for Women and Men During Military Service in the Armed Forces of Ukraine and Other Military Formations" came into force, which equalized the rights of women and men, and duties, and workload, and responsibilities.

The consequences of military service and hostilities often lead to poor health. However, the health of veteran women has not yet been given due attention and care, limited to general military preventive examinations once a year [2].

Among the women participants in the hostilities there are those who have suffered contusions (mild traumatic brain injury), but continue their military service, or, having resigned from it, are active in society.

It should be noted that contusion (concussion and mild concussion) in $73 \%$ of injured is accompanied by mental disorders of the "pre-disease" level (asthenic symptoms, vestibular and autonomic dysfunction, anxiety-depressive inclusions), in $27 \%$ there is a more pronounced psychopathic symptoms [3].

Cognitive and behavioral symptoms include impaired memory and attention, difficulty in making decisions, fatigue, anxiety, depression, irritability, and emotional lability. Patients with such symptoms often describe a slowing of thought processes. These symptoms are usually mild and difficult to detect during routine testing. They decrease in the first 2-4 weeks after injury, but in a small percentage of patients may occur over a long period.

Behavioral symptoms that may occur after a mild TBI include irritability, mood swings, sleep disorders, fatigue, daytime sleepiness, and emotional lability. People with anxiety or depression, posttraumatic stress disorder, and people who abuse alcohol or drugs have a much higher risk of developing these symptoms [4].

At the same time, the problem of health of women veterans and servicemen is not only medical but also social, because not only on the state's defense capabilities depend on the physical, mental and social well-being of this part of the people of Ukraine, but also demographic, sociopolitical and social stability.

The aim of the study: assessing the prevalence and effectiveness of the diagnosis of thyroid dysfunction in women of childbearing age with impaired reproductive health who participated in 
hostilities and suffered contusions, to improve treatment and rehabilitation measures and quality of life of these women.

Materials and methods. The study was conducted at the Department of Obstetrics, Gynecology and Reproductology of the Ukrainian State Institute of Reproductology Shupyk National Medical Academy of Postgraduate Education (NMAPE). The study included 301 women of reproductive age who participated in hostilities and suffered contusions, the average age of the subjects was $27.08 \pm 4.23$ years. The period of stay in the combat zone is $29.34 \pm 9.21$ months, the time from the moment of receiving a mild traumatic brain injury (contusion) is $18.8 \pm 9.2$ months.

At the first stage of the prospective study, the veteran women were interviewed. The structured questionnaire contained questions related to family and personal history, the presence of non-specific symptoms that may be associated with thyroid dysfunction (weakness, fatigue, memory impairment, swelling of the face and extremities, sleep disturbances, dry skin, weight gain body, lethargy, drowsiness, paresthesias, constipation, hair loss, hypochromic iron deficiency anemia, depression, etc.).

Symptoms of the consequences of contusion at the time of examination were determined by the Cicero questionnaire [5]. At the same time, patients performed self-assessment of their own symptoms in view of the present. A PCL questionnaire (military version) was used for PTSD screening [6]. The study of the state of autonomic regulation was carried out by filling out a questionnaire of subjective assessment of dystonia (according to the A. Wayne questionnaire, 1998) [7]. Assessment of the state of the cardiovascular system and autonomic regulation was performed by the method of heart rate variability, which was performed on a heart recorder Solveig DC-06000 and by analyzing the data obtained on the software platform "Cardiolyse". Assessment of the functional state of the organism was performed using a quantum magnetic resonance analyzer "MEDIACOMAT$29 "$ with the calculation of the coefficient of pathology for each system $(\mathrm{Kp}=\Sigma \mathrm{n} / \mathrm{Nmax})$ and the integrated indicator of pathology (IIP $=\Sigma \mathrm{Kp}$ ).

According to the results of the survey, out of the 203 women who were aware of the family history of the disease, $115(38,2 \%)$ noted the presence of thyroid pathology in one of the parents (in $89.8 \%$ of cases - in mother). Nonspecific complaints were noted in $284(94,4 \%)$ of the 301 available questionnaires. Ultrasound examination of the thyroid gland previously underwent $282(93,7 \%)$ women, however, the study of thyroid function (determination of the level of TSH, TPO Antibodies, free T4 and T3) was conducted only in $169(56,1 \%)$ of 301 patients, with subclinical hypothyroidism (TSH from 4.5 to $8.9 \mathrm{IU} / 1)$ was diagnosed in $64(37,9 \%)$ of those who underwent examination, manifest hypothyroidism - in 7 women (4.2\%). Only 11 (6.5\%) patients (7 with manifest and 4 with subclinical hypothyroidism) received levothyroxine treatment as prescribed by an endocrinologist.

According to the results of verification of gynecological pathology, 164 patients who gave informed consent to participate in the second stage of the study, for further comparative analysis of the prevalence of thyroid dysfunction were divided into clinical groups:

- Group I included $55(33,5 \%)$ patients with combined dyshormonal benign proliferative pathology of the reproductive organs and dyshormonal pathology of the breast (genital endometriosis, adenomyosis / uterine leiomyoma in combination with endometrial hyperplasia);

- Group II included 31 (18.9\%) a woman with PCOS;

- Group III - 33 (20.1\%) patients with endometrioid disease;

- Group IV - 37 (22,6\%) women with uterine leiomyoma;

- The absence of gynecological pathology and pathology of the breasts at the time of examination was found in $38(23,2 \%)$ women who were included in group V.

Research results and discussion. Structural and functional changes of the thyroid gland were detected in $164(34,5 \%)$ women, with the frequency of detection of diffuse goiter I-II stages did not differ between clinical groups ( $p>0.05$ ).> At the same time, the prevalence of AIT was higher in patients with dyshormonal pathology of the reproductive system (group I) compared with group V ( $p=0.0001$ ). Euthyroid status in patients with combined dyshormonal and proliferative pathology (group I) was diagnosed 1.5-1.9 times less often than in patients of groups II, III, IV and V ( $\mathrm{p} \leq 0.0005)$.

Subclinical hypothyroidism was diagnosed in $33,5 \%$ of women in group I with $18.9 \%, 20.1 \%$ and $22,6 \%$ in groups II, III and IV, respectively. All patients received levothyroxine at doses calculated according to TSH levels (50 to $75 \mu \mathrm{g}$ / day). At the same time, for group I women with diffuse goiter and / or AIT, the incidence of subclinical hypothyroidism was $60.6 \%$ compared to $8.6 \%$ 
of manifest hypothyroidism not detected in women with PCOS, and the prevalence of endometrioid disease and uterine leiomyoma was respectively $1.9 \%$ and $3.5 \%$.

Conclusions. So, the results of a two-stage study of the prevalence of thyroid dysfunction in women who participated in hostilities and suffered contusions with dyshormonal pathology of reproductive organs of non-inflammatory origin confirm that thyroid dysfunction, especially hypothyroidism, is a serious reproductive health problem in veteran women, which requires changes in diagnostic and treatment approaches.

\section{REFERENCES}

1. Alexander EK, Pearce EN, Brent GA,. Brown RS, et al. 2017 Guidelines of the American Thyroid Association for the Diagnosis and Management of Thyroid Disease During Pregnancy and the Postpartum. Thyroid. 2017; 27 (3): 315- 389. DOI: 10.1089/thy.2016.0457

2. American College of Obstetrics, Gynecologists Committee on Gynecologic P. ACOG Committee Opinion No. 483: Primary and preventive care: periodic assessments. Obstetrics and gynecology. 2011;117:1008-15.

3. Amino N, Tada H, Hidaka Y, Hashimoto K. Hashimoto's disease and Dr. Hakaru Hashimoto. Endocr. J. 2002; 49: 389-391.

4. Brabant PG, Duntas L, Monzani F et al. Management of Subclinical Hypothyroidism 2013 ETA Guideline. Eur. Thyroid. J. 2013; 2: 215-228.

5. Cicerone K. Persistent postconcussion syndrome. Journal of Head Trauma Rehabilitation. 1995; June: 1-17

6. Druz O. B., Syropiatov O. H., Badiuk M. L. [ta in.]. (2015). Udoskonalennia likuvannia ta reabilitatsii viis ko vo sluzhbov tsiv Zbroinykh Syl Ukrainy iz boiovoiu psykhichnoiu travmoiu: metodychni rekomendatsii, Kyiv.: «MP Lesia», 52.

7. James C. Coleman, C. Robert, James Neal Butcher. Abnormal Psychology in Modern Life. - 8-е издание. - Нью- Йорк: HarperCollins Publishers, 1988. - ISBN нет, ASIN: B0025UVCZ0

8. Kyrychenko I. Zdorovia zhinky ta viyna: problema zahystu ta vidnovlennia. Ukraina Moloda, No144, 24.12.2019

9. Ladenson PW, Singer PA, Ain KB, et al. American Thyroid Association guidelines for detection of thyroid dysfunction. Archives of internal medicine. 2000;160:1573-5.

10. Männistö T, Vääräsmäki M, Pouta A. et al. Thyroid dysfunction and autoantibodies during pregnancy as predictive factors of pregnancy complications and maternal morbidity in later life J. Clin. Endocrinol. Metab. 2010; 95(3): 1084-1094.

11. Maruna P. Gynecological aspects of thyroid disorders. A review. Ceska Gynecol. 2006; 71 (4): 332-338.

12. Nyni u viysku sluzhyt maiyzhe 30000- zhinok https://armyinform.com.ua/2020/03/nyni-u-vijsku-sluzhytmajzhe-30-tysyach-zhinok/

13. PTSD: National Center for PTSD: https://www.ptsd.va.gov

14. Razvi S, Weaver JU, Vanderpump MP, Pearce SH. The incidence of ischemic heart disease and mortality in people with subclinical hypothyroidism: reanalysis of the Whickham Survey cohort. J. Clin. Endocrinol. Metab. 2010; 95(4): 1734-1740.

15. Redmond GP. Thyroid dysfunction and women's reproductive health. Thyroid. 2004; 14 (1): 515.

16. Stebliuk Vsevolod, Pronoza-Stebliuk Kate. Post-concussion Syndrome in Ukrainian Veterans: Physical and Mental Manifestations. Journal of Education, Health and Sport. 2018;8(2):349-354

17. Toulis KA, Goulis DG, Venetis CA. et aI. Risk of spontaneous miscarriage in euthyroid women with thyroid autoimmunity undergoing IVF: a meta- analysis. Eur. J. Endocrinol. 2010; 162(4): 643-652.

18. Vein A. M. (2000). Vehetatyvnye rasstroistva: Klynyka, lechenye, dyahnostyka. Moskov. Medytsynskoe ynformatsyonnoe ahentstvo, 752

19. Walsh JP, Bremner AP, Feddema P. et al. Thyrotropin and thyroid antibodies as predictors of hypothyroidism: a 13-year, longitudinal study of a community-based cohort using current immunoassay techniques J. Clin. Endocrinol. Metab. 2010; 95(3): 1095-1104. 